\title{
Parasitoid Dinarmus acutus (Hymenoptera: Pteromalidae) Parasitizing on bruchid beetle, Acanthoscelides macrophthalmus on Leucaena Tree at Alexandria, Egypt
}

\author{
Amany M.H.Abu-shall1and M.E.Tawfeek \\ Department of Applied Entomology and Zoology, Faculty of Agriculture, Alexandria University, Egypt
}

\begin{abstract}
Acanthoscelides macrophthalmus (Schaeffer) (Coleoptera: Chrysomelidae: Bruchinae) hold over high host specificity to Leucaena leucocephala (Lamark) deWit (Fabales: Fabaceae) at Alexandria (Egypt). The infestation rate of the seed beetle and its population fluctuation were determined under natural conditions. The rates were low between February and May 2017, While, it increased and reached a peak in August and decreased in the next January. The parasitoid Dinarmusacutus (Thompson) (Hymenoptera: Pteromalidae) emerged in August with high numbers and reached a peak in September, 2017.

The current study recorded A.macrophthalmus as a new host of $D$. acutus at Alexandria. The average survival rate of A. macrophthalmus and D. acutus until the death of adults were $30 \pm 3$ days and $21 \pm 3$ days, respectively.

This study presented some baseline information regarding the development of $A$. macrophthalmus that may be beneficial as a biological control agent of L. leucocephala at Alexandria, Egypt. In contrast, if L. leucocephala was considered as beneficial tree, the mass rearing of D. acutus should be done to control A. macrophthalmus.
\end{abstract}

Keywords: biological control, population fluctuation, Leucaena leucocephala, seed bruchid beetle, Acanthoscelides macrophthalmus, parasitoid, Dinarmus acutus.

\section{INTRODUCTION}

Acanthoscelides macrophthalmus (Schaeffer) (Coleoptera: Chrysomelidae: Bruchinae) is a seed predator for controlling the weedy shrub Leucaena leucocephala (Lamark) de Wit (Fabales: Fabaceae). Therefore, it is considered to be both a pre- and post-dispersal 'seed predator'(Kergoat et al., 2005; Raghu et al., 2005; Vassiliou and Papadoulis, 2008; Tuda et al., 2009) studies were carried out on this beetle in several countries such as Australia (Raghu et al., 2005), in South-East Asia (Wu et al., 2013) and in Ethiopia (Yirgu et al., 2015). Bruchinae beetles are highly hostspecific seed feeders during the larval stage (Shobam and Olckers, 2010; Wood et al., 2017).

Leucaena leucocephala is a tree/shrub cultivated for fodder, green manure, reforestation, windbreak, fuel, pulp, erosion control and vegetable crop (Barrett, 1990). On the other hand, It eventually became one of the 100 worst invasive alien species in more than 20 countries where it was introduced (Lowe et al., 2000 and Walton, 2003). Its seed production is heavy (up to 1700 pods/tree) and each pod containing approximately 20 seeds (Raghu et al., 2005).

The species richness and evenness of parasitoids attacking the bruchid beetle, $A$. macrophthalmus feeding on L. leucocephala seeds were determined. A total of 1420 parasitoids (Hymenoptera) belonging to four families and five subfamilies were recorded (Wood et al., 2017). Dinarmus acutus (Pteromalidae) is a primary parasitoid of many species of bean weevils
(Bruchinae) and distributed for the fauna of the world (Gupta et al., 1997; Andriescu and Mitroiu, 2004; Ghahari et al., 2010; Tselikh, 2012; Noyes, 2014; Dzhanokmen, 2015; Alrubeai, 2017; Tselikh and Kostjukov, 2017).

A. macrophthalmus was first recorded in Egypt by Mohammad (2017). But, there are no studies about the efficacy of it as a biological control agent. This study aims to determine the population fluctuation of $A$. macrophthalmus and its parasitoid, D. acutuson L. leucocephala at Alexandria, Egypt. This information is necessary to use A. macrophthalmus as a biological agent for control invasive weed $L$. leucocephala or a host for rearing the parasitoid D. acutus in a mass production for biological control.

\section{MATERIALS AND METHODS}

1-Natural infestation of Acanthoscelides macrophthalmus on Leucaena leucocephala:-

Infestation by $A$. macrophthalmus was followed in five trees of Leucaena leucocephala planted in different parts around the Faculty of Agriculture, University of Alexandria, ElShatby district. Weekly random pick up of 50 ripe pods on 5 unlike trees (10 pods from each tree) of $L$. leucocephala were collected throughout the year 2017. The ripe pods were transferred inside paper packages to the laboratory. In the laboratory, the collected pods and their seeds were examined carefully under a dissecting microscope at 20 to 40 magnifications. The pods and seeds of Leucaena infested by $A$. macrophthalmus contained exit circular neat holes, but bigger in diameter than the 
exit hole by parasitoid Dinarmus acutus (Fig. 1). According to Sanders et al. (2013) A.macrophthalmus establish circular exit holes middling $1.7 \mathrm{~mm}$ in diameter in both seed and pod. While, holes from the parasitoid wasp were performed similar to the bruchid beetle exit hole but smaller mean $0.6 \mathrm{~mm}$ in diameter.

Infested pods and percentage of natural infestation (\%predation rate) of the pods and seeds by beetles of $A$. macrophthalmus were counted. From the counts, mean number of seed bruchid beetle per pod and percentage of unemerged beetles of $A$. macrophthalmus (the mummified remains as adults in exit hole) (Fig. 2) per pod were determined.

2- Population fluctuation and development of A. macrophthalmus and its parasitoid wasp, Dinarmus acutus:-

The present work was carried out under prevailing natural field conditions in six locations at Alexandria [gardens of El-montaza $\left(31^{\circ}\right.$ $\left.17^{\prime} 18.582^{\prime \prime} \quad \mathrm{N}, \quad 30^{\circ} 57^{\prime} 488^{\prime \prime} \mathrm{E}\right)$, Antoniads (31 13'18.004" N, 29 $\left.56^{\prime} 48.042^{\prime \prime} \mathrm{E}\right)$, Faculty of Agriculture El-Shatby $\left(31^{\circ} 12^{\prime} 18.62^{\prime \prime} \mathrm{N}\right.$, $29^{\circ} 55^{\prime} 8.86^{\prime}$ 'E), Police hospital (31 ${ }^{\circ}$ 9'55.223.582" $\left.\mathrm{N}, 29^{\circ} 56^{\prime} 0.005^{\prime} \mathrm{E}\right)$, Alexandria Agricultural road $\left(30^{\circ} 48.0316 \mathrm{~N}, 30^{\circ} 59.8407 \mathrm{E}\right)$ and Smouha $\left(31^{\circ}\right.$ $21^{\prime 2} 29.17$ ” N, 29 98'78.06” E)], Egypt. Climatic mean values during the year of 2017 , obtained from data reported by the weather station: 623180 (HEAX), Ministry of Agriculture as showing in Table (1). This ecological zone is characterized by monthly mean temperatures from 15 to $32^{\circ} \mathrm{C}$ throughout the year and relative humidity fluctuated between $65 \%$ and $87 \%$ during this season at Alexandria, Egypt.
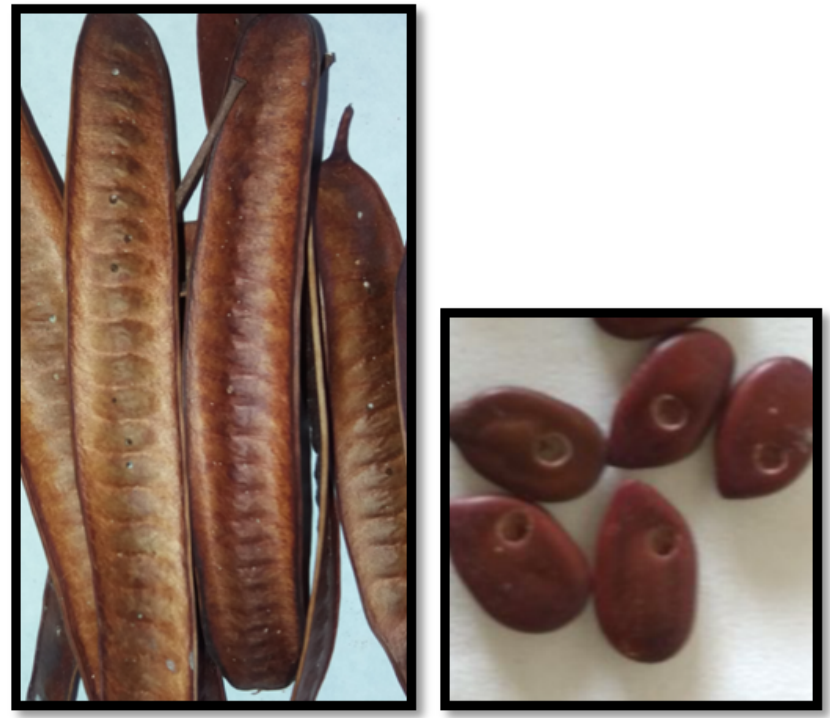

(A)

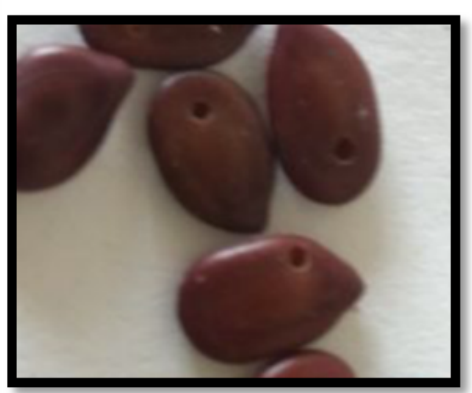

(B)

Figure 1: (A) The exit circular holes of Acanthoscelides macrophthalmus on pods and seeds of Leucaena leucocephala.

(B) The exit hole by parasitoid, Dinarmus acutus on seeds.

(C)

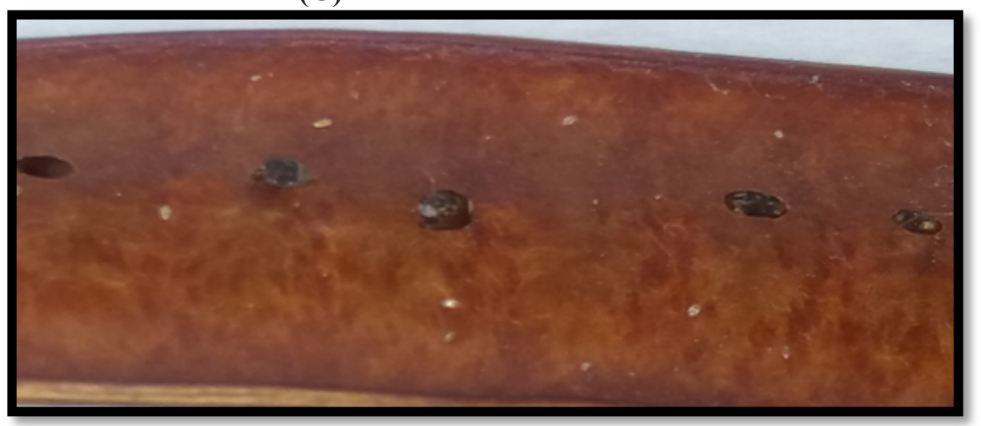

Figure 2: The mummified remains of un-emerged Acanthoscelides macrophthalmus adults in exit hole on pods of Leucaena leucocephala. 
The population fluctuation of $A$. macrophthalmus and its parasitic wasp, Dinarmus acutus were estimated from January 2017 on $L$. leucocephala. Five of leucaena trees were selected in each of the chosen locations with fix-space plant established. From each tree, 10 pods were collected monthly (50 pods per location). Samples of mature pods were taken and put in labeled paper packages. Mature pods were placed in covered plastic jars in the ambient conditions $\left(28 \pm 2^{\circ} \mathrm{C}\right.$ and $75 \pm 5 \%$ $\mathrm{RH}$ ) in the laboratory. Each plastic jar was fixed to dark muslin cloth and covered in the top by plastic cover provided with glass tube for trapping adults of A. macrophthalmus and D. acutus (Fig. 3). Emerging bruchid beetles and the parasitoid in the glass tubes were picked up and counted daily. The removed adults of $A$. macrophthalmus and $D$. acutus from each tube were put separately in labeled glass vial and covered with muslin cloth, then observed daily until death of adults. Male and female adults of $A$. macrophthalmus and D. acutus were identified by morphological traits (Fig. 4). This information is essential to calculate the sexual ratio and survival rate of $A$. macrophthalmus and D. acutus in nature conditions at Alexandria, Egypt.

Table 1: Climatic mean values during 2017 at Alexandria, Egypt.

\begin{tabular}{lcc}
\hline \multirow{2}{*}{ Season 2017 } & \multicolumn{2}{c}{ Climatic mean values } \\
\cline { 2 - 3 } & Temperature $\left.\mathbf{~}^{\mathbf{0}} \mathbf{c}\right)$ & $\mathbf{R H \%}$ \\
\hline January & $17.3 \pm 1.9$ & $70 \%$ \\
\hline February & $18.5 \pm 2.6$ & $68 \%$ \\
\hline March & $21.1 \pm 2.01$ & $65 \%$ \\
\hline April & $23.6 \pm 2.6$ & $65 \%$ \\
\hline May & $27.8 \pm 3.9$ & $67 \%$ \\
\hline June & $29.5 \pm 2.5$ & $81 \%$ \\
\hline July & $30.8 \pm 2.7$ & $80 \%$ \\
\hline August & $31.9 \pm 0.6$ & $78 \%$ \\
\hline September & $29.2 \pm 1.2$ & $87 \%$ \\
\hline October & $27.7 \pm 5.6$ & $77 \%$ \\
\hline November & $24.1 \pm 4.7$ & $80 \%$ \\
\hline December & $19.2 \pm 1.3$ & $70 \%$ \\
\hline
\end{tabular}

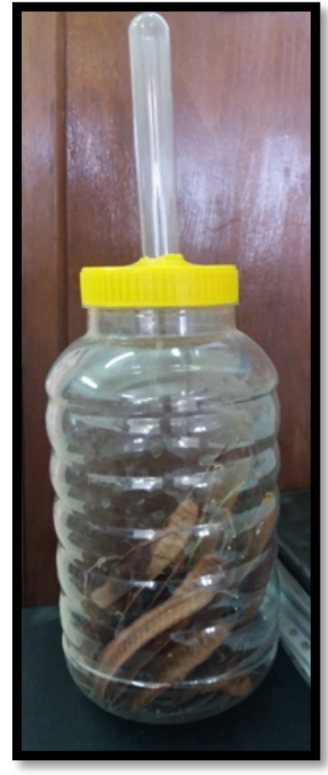

(A)

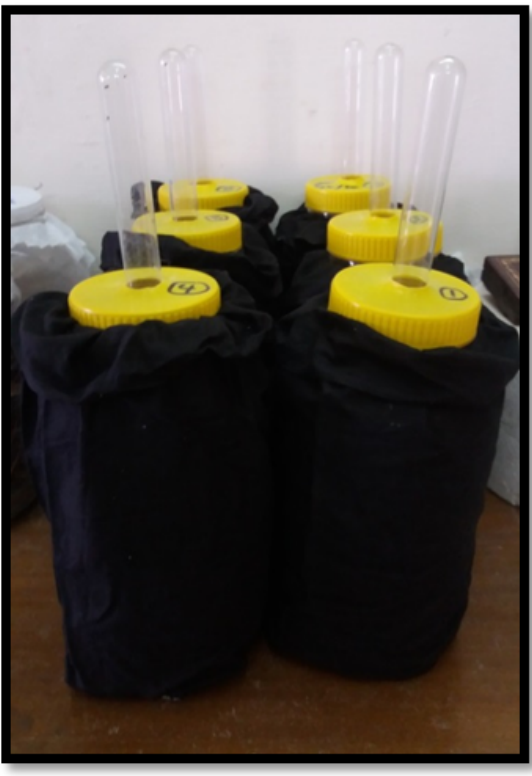

(B)

Figure 3: (A) Plastic jar provided with glass tube for trapping adults of Acanthoscelides macrophthalmus and Dinarmus acutus.

(B) Plastic jarscovered with dark muslin cloth. 


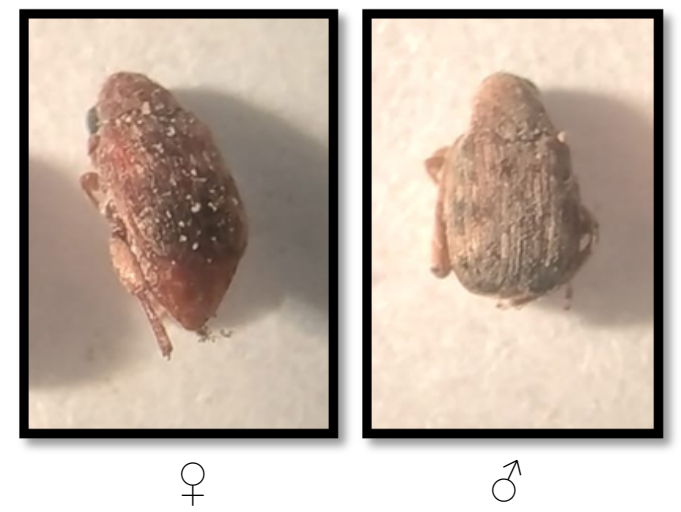

(A)

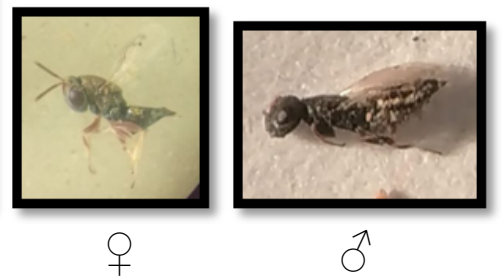

(B)

Figure 4: (A) Adults ( $q$ and $\bigcirc$ ) of Acanthoscelides macrophthalmus. (B)Adults ( $q$ and $\curvearrowright$ ) of Dinarmus acutus.

3- Morphometeric measurements of the hymenopterous parasitoid Dinarmus acutus:-

Measurements of ten individuals from each males and females of the parasitoid Dinarmus acutus were conducted using research microscope and micrometer lens. The means of ten measurements in $\mathrm{mm}$ were obtained with Standard deviation.

\section{4- Statistical analyses:-}

The mean numbers of the distinct parameters of the experiments were calculated using the analysis of variance test (ANOVA), with the mean separation at 5\% level of significance using computer program Costat according to the method of Snedecor and Cochran (1967).

\section{RESULTS AND DISCUSSION}

1-Natural infestation of Leucaena leucocephala by Acanthoscelides macrophthalmus:-

The mature pods of Leucaena leucocephala infested by $A$. macrophthalmus were $72 \pm 7.8 \%$ from all the collected pods and the in general average percentage of seed loss due to infestation by this beetle were $80 \pm 7.7 \%$. Emerged percent of A. macrophthalmus adults were $69 \pm 7.3 \%$ from the pods on both sides, which contained the exit circular holes to the bruchid beetle. But, the mummified remains of un-emerged $A$. macrophthalmus adults in exit hole on pods of $L$. leucocephala were $11 \pm 7.6 \%$ from both sides
(Table 2). The present study showed that uninfested pods contained $(7.9 \pm 0.2)$ intact seeds, while pods infested by this beetles included significantly $(\mathrm{P}<0.05)$ reduced number of intact seeds $(2.6 \pm 0.2)$. Previous studies indicated that between 8 and 30 seeds are created per uninfested pod (Walton, 2003; ISSG, 2006; Sankaran, 2007). An average of 14.67 seeds per pod was collected (Sanders et al., 2013).

The present data shoewd that $A$. macrophthalmus reduce seed production in $L$. leucocephala. Green and Palmbald (1975) established that the seed predation by Acanthosce iides fraterculus (Horn) overstep $60 \%$ in Astragalus cibarius Sheld. And Astragalus utahensis (Tom) populations, and reach nearly $100 \%$ (Rogers and Garrison, 1975) in natural plant communities, and this variation related to years and locations (Baskin and Baskin, 1977). Seed predation of Glycyrrhiza lepidota Pursh vary between 7 and $71 \%$ with an general average of 41 $\pm 2 \%$ (Boe and Wynia, 1985). So, Legume seed predation by bruchid beetles may overstep $50 \%$. While, Boe et al. (1989) found 36\% of the pods included Acanthosce iides perforatus (Horn) (Coleoptera: Bruchinae) in both lobules and larvae of the seed predator taken place in $77 \%$ of the mature pods.

Table 2: The infested pods and percentage of predation rate by beetles of Acanthoscelides macrophthalmus on Leucaena leucocephala during 2017 at Alexandria, Egypt.

\begin{tabular}{|c|c|c|c|c|}
\hline \multirow{2}{*}{$\begin{array}{l}\text { \%Infested } \\
\text { pods }\end{array}$} & \multirow{2}{*}{$\begin{array}{l}\text { Mean number of } \\
\text { beetles } / \operatorname{pod} \pm \text { S.E }\end{array}$} & \multicolumn{2}{|c|}{ \% Predation rate by beetles } & \multirow{2}{*}{$\begin{array}{c}\% \text { unemerged beetles } \\
\text { from pods }\end{array}$} \\
\hline & & pods & seeds & \\
\hline $72 \pm 7.8$ & $13.25 \pm 2.1$ & $69 \pm 7.3$ & $80 \pm 7.7$ & $11 \pm 7.6$ \\
\hline
\end{tabular}

-Means significantly different at the 0.05 level.

- Means of 5 different trees of L. leucocephala; 10 pods per tree (50 sample). 
Johnson, 1981 stated that seeds of $L$. leucocephala are small (about $1.5 \mathrm{mg} / \mathrm{seed}$ ), and mean number beetles of $A$. macrophthalmus devoured seeds about $13.25 \pm 2.1$ per pod, one or more bruchid larvae feed and develop inside a single seed in large-seeded legumes. While, the larvae of $A$. perforatus devoured from 2 to 12 seeds (Boe et al., 1989).

A. macrophthalmus has been invaded West Africa, feeding on the host plant, L. leucocephala (Delobel and Johnson, 1998). Since 1999 this bruchinae species has been introduced in South Africa for biological control of L. leucocephala (ARC-PPRI, 2003; Olckers, 2004). Only, A. macrophthalmus was used as bio-agents control of weedy plants and emerge from the seeds of $L$. leucocephala (Tuda et al., 2009). A. macrophthalmus emerged from $L$. leucocephala was able to place eggs and hatching larvae were able to feed on L. leucocephala seeds, after that bruchid beetles emerged from these seeds. Our review of the issued work indicated that $A$. macrophthalmus had high host specificity to genus Leucaena not in native regions only but also in introduced regions (Pfaffenberger and Johnson, 1976; Johnson, 1979; Jones, 1996; Hughes and Johnson, 1996; Delobel and Johnson 1998; Tuda et al., 2009; Olckers and Welsford, 2013; English and Olckers, 2014).

2- Population fluctuation of $\boldsymbol{A}$. macrophthalmus and its parasitoid, Dinarmus acutus during 2017 at Alexandria, Egypt:-

This study identified Dinarmus acutus as a parasitoid of $A$. macrophthalmus and showed its direct effect on the reproductive capacity of the plant $L$. Leucocephala and population fluctuation of A. macrophthalmus. These findings propose that explanation of the interactions between host plant, bruchind beetles, and the hymenopterous parasitoid is important to comprehending their ecology and population fluctuation. The effect of bruchid beetles on long-term seed production of native legumes and the efficacy of hymenopterous parasitoids for reducing seed losses can be decided after more extend evaluation.

2-1.Temporal variation of $A$. macrophthalmus and parasitic wasp, $D$. acutus density

In the laboratory, collected L. leucocephala pods from six locations showed that $A$. macrophthalmus is present all the year. The number of emerged A. macrophthalmus adults was low during the first half of the season 2017, between February and May. Number of adult's emergence increased from June and arrived a peak in August, and starting to decrease up to January. On the other hand, adults of parasitoid began to emerge in August with high numbers and reached a peak in September, but only a few adults of $A$. macrophthalmus emerged during this time of 2017 (Fig. 5).

The present results agree with that of Elder (2002) and Effow et al. (2010) who mentioned that the females of bruchid beetle deposit their eggs throughout the year on ripe pods. The infestation rates of this beetle were low between February and March, corresponding to the majority of $L$. leucocephala trees partially loses their foliage and dry pods. These old pods did not prefer to be selected by the females for oviposition. But, the rates of infestation increased in April and a maximum rate of assault taken place between August and December (64 and $72 \%$ of the pods were charged). This period corresponds to the good flowering and new pods that are preferentially chosen by females for oviposition

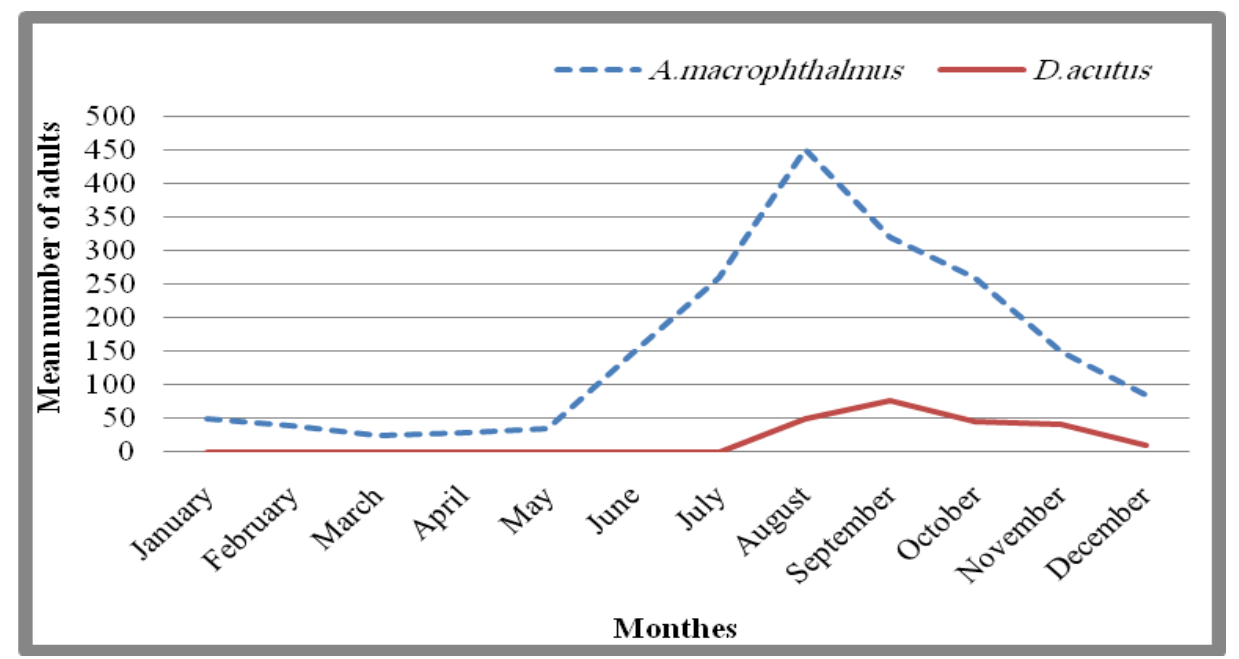

Figure 5: Population fluctuation of Acanthoscelides macrophthalmus and its parasitoid, Dinarmus acutus during 2017 at Alexandria, Egypt. 
The parasitoid Dinarmus acutus was parasitizing Acanthoscelides macrophthalmus as a new host recorded throughout the present study in Alexandria, Egypt. This parasitoid has been breeded from Bruchidius ater (Marsham) and Bruchus brachialis Fahr. (Krombein et al., 1979) and registered from many of seed legumes including Acanthoscelides fraterculus, A. griseolus (Fall) (Johnson, 1970) and A. perforatus (Boe et al., 1989). D. acutus had a straight effect on $L$. leucocephala by decreasing the number of seeds devoured by larvae of $A$. perforatus. Since larvae of $A$. perforatus consumed more food of seeds $85 \%$ than those parasitized by D. acutus 62\% (Boe et al., 1989). Fabres and Reymonet (1991) found that the ectoparasite D. Acutus emerge in small numbers in autumn of the same year and then abundantly in spring of the following year after a diapause in the last larval stage. While, few of the D. acutus adults were found during July or early August, and more between mid- August to September (Leong and Dickason, 1975).

2-2. Adult survival of $\boldsymbol{A}$. macrophthalmus and its parasitoid, $D$. acutus in the laboratory

In laboratory, the survival rate of $A$. macrophthalmus and its parasitoid, D. acutus until the death of adults were $30 \pm 3$ days and $21 \pm 3$ days, respectively. The adult female of both $A$. macrophthalmus and D. acutus lived from two to three weeks.

During the development of $A$. macrophthalmus and the parasitic wasp, D. basalis in laboratory, the total developmental period (egg to adult) continued $33.8 \pm 2.9$ days and $33.4 \pm 2$ days on pods and seeds, respectively. These means were different according to substrate of oviposition; which was longer on pods than on seeds. The development was low at the first stages because of very hardness of the tegument of L. leucocephala seeds that can create a barrier for the perception of the first instars inside the seed (Mondedji et al., 2002). This is the main reason to describe the long development of $A$. macrophthalmus when the eggs are laid on pods as compared to on seeds (Effowe et al., 2010).

During their lifetime, the sex-ratio $(\delta:$ 응 was approximately 1: 1.5 and 1: 2.7, when calculated from the adults of $A$. macrophthalmus and its parasitoid, D. acutus emerged from collected pods, respectively, during this season of 2017. Under laboratory conditions, a female of $D$. acutus produced 35 offspring in a sex ratio of $1: 1$. Females preferred mature pods infested with bruchid and $4^{\text {th }}$ larval instars. The egg was deposited inside the cavity of seed on the body surface of the bruchid host. The larval stage of this external parasite consists of 3 larval instars and overwintered as a $3^{\text {rd }}$ instar inside seeds. The life cycle required for completion from egg to adult about 24 days and 10 months in non-overwintering and overwintering brood, respectively (Leong and Dickason, 1975). Also, Effowe et al. (2010) found that the sex-ratio of $A$. macrophthalmus on pods and seeds were $50.3 \%$ and $50.9 \%$ females in southern Togo (West Africa), respectively.

\section{3- Morphometeric measurements of the hymenopterous parasitoid Dinarmus acutus:-}

During this study, observation showed that the size of $A$. macrophthalmus adults was different between beginning and the end of the season. Haga and Rossi (2016) reported that the L. leucocephala seed characteristics influence on the body size and of $A$. macrophthalmus. According to that variation in measurements of body size of the parasitoid $D$. acutus adults was appeared. So, the measurements of males and females of the parasitoid D. acutus adults were accomplished and the mean \pm Standard deviation in $\mathrm{mm}$ were given in Table (3).

Future studies are required to determine the relation between the size of $A$. macrophthalmus larvae and the size of its parasitoid D. acutus.

\section{CONCLUSION}

The bruchid beetle, Acanthoscelides macrophthalmus (Schaeffer) (Coleoptera: Chrysomelidae: Bruchinae) oviposit on seed pods of the tree Leucana leucocephala (Lam.). The beetles lay their eggs on seed pods and on loose seeds of its host. Hatching larvae burrow into the seeds to consume the contents, emerging as adults. It was released as biological control agent to reduce the invasive Neotropical tree Leucaena leucocephala in certain countries.

Table 3: Mean \pm S.D. measurements $(\mathrm{mm})$ of males and females of the parasitoid Dinarmus acutus adults on its host Acanthoscelides macrophthalmus at Alexandria, Egypt.

\begin{tabular}{lccccc}
\hline \multicolumn{5}{c}{ Mean \pm S.D. of the parasitoid D. acutus adults } \\
\hline Male & \multicolumn{4}{c}{ Female } \\
\hline L. Body & L. Ant. & L. Wi. & L. Body & L. Ant. & L. Wi. \\
\hline $0.2153 \pm 6.7$ & $0.54 \pm 3.4$ & $0.129 \pm 2.9$ & $0.371 \pm 16.6$ & $0.106 \pm 1.2$ & $0.214 \pm 2.1$ \\
\hline
\end{tabular}

*Abbreviations: L. Body= The length of Body, L. Ant. = The length of Antenna, L. Wi. = The length of Wing.

*data from 10 individuals. 
The data in this study introduce, some information regarding the development of $A$. macrophthalmus that may be beneficial for its promotion as a biological control agent, if $L$. leucocephala was considered as invasive weed in Egypt. The parasitoid, Dinarmus acutus (Thompson) (Hymenoptera: Pteromalidae) was recorded for the first time on A.macrophthalmus at Alexandria, Egypt. If the Neotropical tree $L$. leucocephala consider as beneficial agroforestry, A. macrophthalmus could be used as a host for rearing the parasitoid $D$. acutus in a mass productionto biocontrol A. macrophthalmus.

\section{AKNOWLEDGMENT}

Authors deeply thank Dr. Nevein Gad Allah professor of Entomology - faculty of Science Cairo University who identify the parasitoid, D. acutus

\section{REFERENCES}

Alrubeai, H. F. (2017). Biological Control of Insect Pests in Iraq: 1) an Overview of Parasitoids and Predators Research Development. Academic Journal of Entomology. 10 (2): 1018.

Andriescu, J. and Mitroiu, M. D. (2004). "Notes on the Pteromalid Fauna (Hymenoptera: Chalcidoidea, Pteromalidae) of Dobrogea, Romania (II)," An. Şti. Univ. "AL. I. CUZA" laşi, serie Biologie animal. 50, 89-96.

[ARC-PPRI] Agricultural Research Council-Plant Protection Research Institute (2003). Releases of biological control agents against weeds in South Africa.

http://155.240.199.39/institutes/ppri/main/ divisions/weedsdiv/releases.htm.

Barrett, R. P. (1990). Legume species as leaf vegetables. In: Janick J, Simon JE (eds) Advances in New Crops. Timber Press, Portland, OR. 391-396.

Baskin, J. M. and Baskin, C. C. (1977). Predation of Cassia marilandica seeds by Sennius abbreviatus (Coleoptera: Bruchidae). Bull. Torr. Bot. Club. 104: 61-64.

Boe, A. and Wynia, R. (1985). Seed predation, seedling emergence, and rhizome characteristics of American licorice. Journal of Range Management. 38: 400-402.

Boe, A., MCDniel, B., and Robbins, K. (1989). Direct effect of parasitism by Dinarmus acutus Thomson on seed predation by Acanthoscelides perforatus (Horn) in Canada milk-vetch. J. Range Manage. 42(6): 514-515.

Delobel, A. and Johnson, C. D. (1998). First record of a seed-beetle on Leucaena leucocephala in West Africa. Leucnet News. 5: 25-26.
Dzhanokmen, K. A. (2015). Pteromalids (Hymenoptera, Chalcidoidea: Pteromalidae) of the Sajram-Ugam State National Nature Park in Western Tien Shan. Entomological Review, 95(4): 456-471.

Effowe, T. Q., Amevoin, K., Nuto, Y., Mondedji, D. and Glitho, I. A. (2010). Reproductive capacities and development of a seed bruchid beetle, Acanthoscelides macrophthalmus, a potential host for the mass rearing of the parasitoid, Dinarmus basalis. Journal of Insect Science. 10: 129. ISSN: 1536-2442.Online at: insectscience.org/10.129.

Elder, R. (2002). Leucaena seed bruchid in Leucaena. DPI Note 3181, Available online: http://www2.dpi.qld.gov.au/beef/3181.html.

English, K. F. and Olckers, T. (2014). Does the size of the seeds and seed pods of the invasive tree Leucaena leucocephala (Fabaceae) affect their utilization by the biological control agent Acanthoscelides macrophthalmus (Chrysomelidae: Bruchinae). African Entomology. 22(4): 872-879.

Fabres, G. and Reymonet, C. (1991). L'induction maternelle de la diapause larvaire chez Dinarmus acutus [Hym.: Pteromalidae]. Entomophaga. 36(1): 121-129.

Green, T. W. and Palmbald, I. G. (1975). Effects of insect seed predators on Astragalus cibarius and Astragalus utahensis (Leguminosae). Ecology. 56: 1435-1440.

Gupta, H. C., Gupta, I. J. and Sharma, S. N. (1997). Parasitic wasps, Dinarmus acutus (Thompson) and Dinarmus basalis (Rondani) (Hymenoptera: Pteromalidae) parasitizing pulse beetle Callosobruchus maculatus (Fabricius). Journal of Biological Control. 11 (1/2): 77-78.

Haga, E. B. and Rossi, M. N. (2016). The effect of seed traits on geographic variation in body size and sexual size dimorphism of the seedfeeding beetle Acanthoscelides macrophthalmus. Ecology and Evolution. 6 (19): 6892-6905.

Hughes, C. E. and Johnson, C. D. (1996). New host records and notes on Bruchidae (Coleoptera) from Leucaena Benth. (Leguminosae, Mimosoideae) from Mexico, Central and South America. Journal of Applied Entomology. 120: 137-141.

ISSG.(2006). Ecology of Leucaena leucocephala. In: Invasive Species Specialist Group (ISSG) (Eds) Global Invasive Species Database. http://www.issg.org/database/species/ecology. asp? fr $=1 \& s i=23$ (accessed 11 April 2011). 
Johnson, C. D. (1970). Biosystematics of the Arizona, California, and Oregon species of the seed beetle genus Acanthoscelides Schilsky (Coleoptera: Bruchidae). Univ. Calif. Pub. Entomol. 59: 1-116.

Johnson, C. D. (1979). New host records for Acanthoscelides (Coleoptera: Bruchidae). PanPacific Entomology. 55: 61-71.

Johnson, C. D. (1981). Seed beetle host specificity and the systematics of the Leguminosae. In: Polhill RM, Raven PH (eds) Advances in Legume Systematics Part 2. Royal Botanical Gardens, Kew. 995-1027.

Jones, R. M. (1996). Leucaena beetle now in Australia. Leucn et News. 3: 19-20.

Kergoat, G. J., Alvarez, N., Hossaert-Mckey, M., Faure, N. and Silvain, J. F. (2005). Parallels in the evolution of the two largest New and Old World seed-beetle genera (Coleoptera, Bruchidae). Molecular Ecology. 14: 40034021.

Krombein, K. V., Hurd, P. D., Smith, D. R. and Burks, B. D. (1979). Catalog of Hymenoptera in America north of Mexico. Washington: Smithsonian Institution Press. Vol. l: Symphyta and Apocrita (Parasitica). xvi + 11198.

Leong, K. L. and Dickason, E. A. (1975). Biology of Dinarmus acutus, a chalcidoid parasite of the vetch bruchid. Annals Entomological Society of America. 68(6): 943-948.

Lowe, S., Browne, M., Boudjelas, S. and De Poorter, M. (2000). 100 of the World's Worst Invasive Alien Species: A selection from the Global Invasive Species Database. The Invasive Species Specialist Group (ISSG) a specialist group of the Species Survival Commission (SSC) of the World Conservation Union (IUCN), Auckland.

Mohammad, Rehab, R. EL. (2017). Studies on Some Coleopterous Tree Borers. M.Sc. Thesis, Faculty of Agriculture, Alexandria University. $112 \mathrm{pp}$.

Mondedji, D., Amevoin, K., Nuto, Y. and Glitho, I. A. (2002). Potentiel reproducteur de Dinarmus basalis Rond. (Hymenoptera: Pteromalidae) en présence de son hôte Callosobruchus maculatus F. (Coleoptera : Bruchidae) en zone guinéenne. Insect Science and Its Application. 22 (2): 113-121.

Noyes, J. S. (2014). Universal Chalcidoidea Data base. World Wide Web Electronic publication, Natural History Museum, Available from: http//www.nhm.ac.uk / Chalcidoids/ (updated: May 2014).
Olckers, T. (2004).Targeting emerging weeds for biological control in South Africa: the benefits of halting the spread of alien plants at an early stage of their invasion. South African Journal of Science. 100: 64-68.

Pfaffenberger, G. S. and Johnson, C. D. (1976). Biosystematics of the first-stage larvae of some North American Bruchidae (Coleoptera). Agricultural Research Service, United States Department of Agriculture, Technical Bulletin.1525: 1-75.

Raghu, S., Wiltshire, C. and Dhileepan, K. (2005). Intensity of pre-dispersal seed predation in the invasive legume Leucaena leucocephala is limited by the duration of pod retention. Austral. Ecology. 30: 310-318.

Rogers, C. E. and Garrison, J. C. (1975). Seed destruction in indigobush Amorpha by a seed beetle. J. Range Manage. 28: 241- 242.

Sanders, B. S., Kjar, D. S. and Egan, T. P. (2013). Beetle (Coleoptera: Bruchidae: Acanthoscelides macrophthalamus) seed predation on Leucaena leucocephala (Fabaceae: Mimosoideae) seeds and pods in two habitats on San Salvador Island, Bahamas. In: C. Tepper and R. Shaklee, eds., Proceedings of the 14th Symposium on the Natural History of the Bahamas. Gerace Research Centre, San Salvador, Bahamas. 5358.

Sankaran, K. V. (Ed). (2007). Leucaena leucocephala. Newsletter of the Asia-Pacific Forest Invasive Species Network (APFISN).

Snedecor, G. W. and Cochran, W. G. (1967). 'Statistical methods'. $6^{\text {th }}$ Ed. Oxford \& IBH. Publ. Co. Calcutta. Bombay, New Delhi. 593pp.

Tselikh, E.V. (2012). "Hymenoptera, Pteromalidae". In Annotated Catalog of the Insects of the Russian Far East. Vol. 1, Ed. by Lelej, A.S. (Dalnauka, Vladivostok).150-161. [in Russian].

Tselikh, E. V. and Kostjukov, V. V. (2017). New Data on the Pteromalid Wasps (Hymenoptera, Chalcidoidea: Pteromalidae) of Krasnodar Territory (Russia). Entomological Review. 97(1): 44-56.

Tuda, M., Wu, L. H., Tateishi, Y., Niyomdham, C., Buranapanichpan, S., Morimoto, K., Wu, W. J., Wang, C. P., Chen, Z. Q., Zhu, H. Y., Zhang, Y. C.,Murugan, K.,Chou, L. Y. and Johnson, C. D. (2009). A novel host shift and invaded range of a seed predator, Acanthoscelides macrophthalmus (Coleoptera: Chrysomelidae: Bruchinae), of an invasive weed, Leucaena leucocephala. Entomological Science. 12(1): 1-8. 
Vassiliou, V. A. and Papadoulis, G. (2008). First record of Acanthoscelides macrophthalmus (Schaeffer) (Coleoptera: Bruchidae) in Cyprus. Entomologia Hellenica. 17: 52 - 55.

Walton, C. S. (2003). Leucaena leucocephala in Queensland. Pest Status Review Series -Land Protection, Department of Natural Resources and Mines, Queensland.50 pp.

Wood, A., Haga, E. B., Costa, V. A. and Rossi, M. N. (2017). Geographic distribution, large-scale spatial structure and diversity of parasitoids of the seed-feeding beetle Acanthoscelides macrophthalmus. Bulletin of Entomological Research. 107 (3): 322-331.
Wu, L. H., Wang, C. P. and Wu, W. J. (2013). Effects of temperature and adult nutrition on the development of Acanthoscelides macrophthalmus, a natural enemy of an invasive tree, Leucaena leucocephala. Biological Control. 65: 322-329.

Yirgu, A., Gezahgne, A. and Tsega, M. (2015). First report of Acanthoscelides macrophthalmus (Schaeffer) on Leucaena leucocephala (Lam.) de wit in Ethiopia and a preliminary investigation into its impacts. African Entomology. 23 (2): 280-285.

\section{طفيل Dinarmus acutus(Hymenoptera: Pteromalidae) المتطقل على خنفساء Acanthoscelides macrophthalmus الإسكندرية، مصر

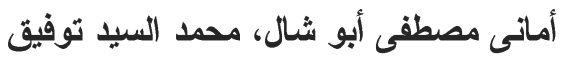

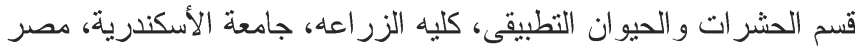

(Coleoptera: Chrysomelidae: Bruchinae) Acanthoscelides macrophthalmus(Schaeffer) تتطفـل حس على قرون أثنجار الليوسينا Fabales: Fabaceae) Leucaena leucocephala (Lamark) deWit فى مـصـر • تمــت

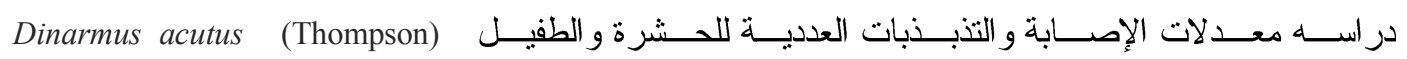
تحت الظروف الطبيعية خلال عام Y.IV (Hymenoptera: Pteromalidae) كانت منخفضة خلال شهرى فبر اير حتى شهر مايو ووصلت إلى قمة التعداد فى شهر أغسطس وإنخفضت مـرة

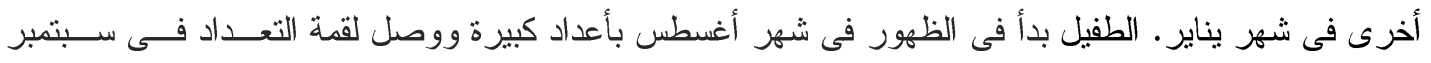
$. r+1 Y$

أظهرت الدر اسة الحالية أن خنفساء A. macrophthalmus تعتبر عائل جديد للطفيل acutus . في الإسكندرية.

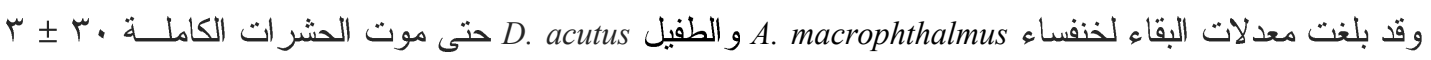

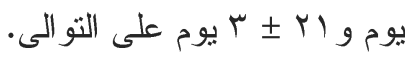

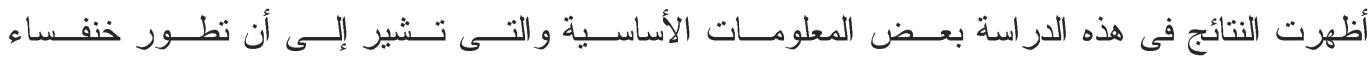
A. macrophthalmus

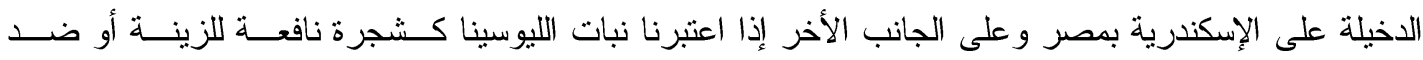

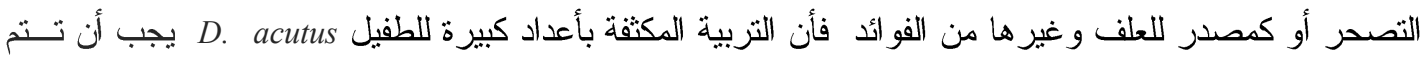
للقضاء على خنفساء A. macrophthalmus التى تسبب فقد كبير لبذور الليوسينا. 